\title{
Tobacco smoking among pediatric residents in Argentina. Current prevalence and trend over the past 10 years
}

\author{
Emiliano Gigliotti, M.D., ${ }^{a}$ Fernando Ferrero, M.D., ${ }^{a}$ Claudio Castaños, M.D. ${ }^{b}$ \\ María Teresa Blengini, M.D., ${ }^{c}$ Pablo Durán, M.D., ${ }^{a}$ Laura Moreno, M.D. ${ }^{c, d}$ \\ and the Study group on smoking among pediatric residents*
}

\begin{abstract}
Introduction. Pediatricians are in a strategic position to prevent smoking.

Objectives. To estimate the prevalence of smoking among pediatric residents, analyze associated factors, describe preventive actions, and assess the differences observed over the past decade.

Methods. Cross-sectional study with a selfadministered, anonymous survey conducted among pediatric residents from eight Argentine hospitals. Smoking habit, associated factors, and attitude towards patients' or their parents smoking were evaluated; results were compared to those obtained in 2002.

Results. Out of 448 surveyed physicians, 20.1\% smoked.

There were no significant differences between smokers and non-smokers in terms of gender, having children, number of on-call shifts, and having a supervisor who smokes.
\end{abstract}

a. Hospital Elizalde. Buenos Aires City

b. Hospital Garrahan. Buenos Aires City.

c. Hospital Santísima Trinidad. Córdoba City.

d. Chair of Pediatrics. Universidad Nacional de Córdoba.

e. Hospital Castro Rendón. Neuquén City.

f. Hospital Infantil. Córdoba City.

g. Hospital Notti Mendoza City.

h. Hospital Sor María Ludovica. La Plata City, Buenos Aires Province.

i. Hospital Gutiérrez. Buenos Aires City

E-mail address:

Emiliano Gigliotti,

M.D.: emigigliotti@

hotmail.com

Conflict of interest: None.

Received: 10-9-2012

Accepted: 2-16-2013
The rate of active behavior regarding patients or parents who smoke was very low. In spite of official policies, tobacco use in this group has not changed over the past decade, but there was an increase in the rate of those who received information during their training and of those who advised their patients of smoking risks. Key words: residency and internship, tobacco, smoking, smoking cessation, professional role.

http:/ /dx.doi.org/10.5546/aap.2013.315

\section{INTRODUCTION}

Tobacco use is the leading preventable cause of death; it is estimated to cause more than 5 million deaths every year around the world. ${ }^{1}$

Due to tobacco morbidity and mortality, smoking implies a significant financial cost, which can account for up to $15 \%$ of the expenditure on health. ${ }^{2}$

Physicians find themselves in a strategic position to influence their patients' smoking habit. This is particularly important among pediatricians, because they can take actions towards the prevention of smoking initiation among children and adolescents, and encourage their parents to quit smoking, ${ }^{4}$ thus reducing children exposure to environmental tobacco smoke. ${ }^{5}$

Due to the particular work load entailed by the residency and the

\footnotetext{
*Study group on smoking among pediatric residents: Lina Abram, M.D., ${ }^{e}$ María Carolina Amveg, M.D., ${ }^{c}$ Paola Biancotti, M.D., ${ }^{c}$ María T. Blengini, M.D., c Claudio Castaños, M.D., ${ }^{b}$ Laura Castro, M.D., ${ }^{a}$ Silvina Cipriani, M.D., Pablo Colletti, M.D., ${ }^{e}$ Pablo Durán, M.D., ${ }^{a}$ Gastón Fernández, M.D., ${ }^{g}$ Fernando Ferrero, M.D., ${ }^{a}$ Patricia Fignana, M.D. ${ }^{c}$ Ana Figueroa, M.D. $f$ Emiliano Gigliotti, M.D. , ${ }^{a}$ Laura Moreno, M.D. ., ${ }^{c, d}$ Mercedes Posadas, M.D., ${ }^{b}$ Andrea Reinoso, M.D., ${ }^{g}$ Fernando Rentería, M.D., ${ }^{h}$ Viviana Rodríguez, M.D. ${ }^{i}$ Bárbara Sparrow, M.D. ${ }^{i}$ Erica Stelmaszewski, M.D., ${ }^{b}$ and Jorge Urrutigoyti, M.D. ${ }^{g}$
} 
stress suffered by residents, they can be more exposed to smoking. ${ }^{6}$ In 2002, an assessment on the smoking habit among pediatric residents in Argentina was conducted and it was found that $22.1 \%$ of them smoked. ${ }^{7}$ In accordance with the guidelines of the World Health Organization Framework Convention on Tobacco Control, ${ }^{8}$ different related policies have been implemented in Argentina, which led to a reduction in the prevalence of tobacco use from $39.8 \%{ }^{9}$ to $27.1 \%$ over the past 10 years. ${ }^{10}$ It was expected that following government actions, smoking prevalence among resident physicians would be reduced to at least a similar rate.

The objective of this article was to estimate the prevalence of smoking among pediatric residents, assess possible associated risk factors, describe the behavior of surveyed physicians in relation to their patients' or parents' smoking, and compare the results with those obtained in 2002.

\section{MATERIAL AND METHODS}

This was a cross-sectional study with a closed, self-administered, anonymous survey. The study was carried out during May 2011 in the eight Argentine children's hospitals that participated in the prior study: ${ }^{7}$ Elizalde, Garrahan and Gutiérrez (Autonomous City of Buenos Aires), Santísima Trinidad and Infantil (Córdoba), Castro Rendón (Neuquén), Notti (Mendoza) and Sor María Ludovica (La Plata). All resident pediatricians present at their hospital on the day of the survey and who accepted to participate in the research were included, and those who were not working at the hospital at the time of the survey (paid leave, sick day, turnover, day off to complete formalities) were excluded.

Study outcome measures included gender; age; smoking habit; year of residency; number of weekly on-call shifts; household members, if the mother, father or supervisor smoked; age at initiation; hospital place and activities where smoking was more common; if smoking had increased since starting the residency; if information on how to encourage smoking cessation in patients had been received during residency or university training, and their attitude towards patients' or parents' tobacco use (if they asked about smoking, warned about smoking risks, and advised on cessation or not to start smoking). A dichotomous variable "active behavior" was established by assigning an affirmative value only if the subject answered "always" to the three questions about behavior (ask, warn, and advise).
For the purpose of this article, a smoker was defined as an individual who had smoked at least 100 cigarettes, 20 cigars, or 20 pipes, and who was a smoker at the time of the survey.

Sample size: given that there were approximately 1200 pediatric residents in Argentina with a smoking prevalence of $22 \pm 5 \%$, and up to $10 \%$ may have refused to participate, the sample size was estimated at 230 subjects to achieve a $95 \%$ confidence interval. This was a convenience sample because participants were subjects who were taking part in the same residency programs as in 2002 so as to have comparable results. The selected sample comprises approximately $50 \%$ of all pediatric residents in Argentina. It was estimated that at least two thirds of them would be eligible for participation.

Statistical analysis: replies to each outcome measure were distributed using 95\% confidence intervals, or mean and standard deviation, as applicable. The association between each predictor and outcome measure was estimated using the $\chi^{2}$ test or Fisher's exact test, as applicable, by calculating the ORs and the corresponding $95 \%$ confidence intervals. For numerical variables, the difference between means was evaluated using the $t$ test, if their distribution was normal, and the Mann-Whitney $\mathrm{U}$ test, if otherwise.

Finally, two logistic regression models were developed. One model assessed tobacco use among residents including the rest of the outcome measures; the other model explored residents' behavior towards their patients' smoking, including age, gender, personal and parental smoking habits, and information received.

The difference between the results of this study and those obtained in the 2002 study was determined by the $t$ test or the $\chi^{2}$ test, as applicable. A two tailed 0.05 significance level was assumed. Data were analyzed using the SPSS 17.0 software (SPSS Inc., Chicago, USA, 2002).

Ethical considerations: approval was requested to and obtained from each institution's Ethics Committee or Research Committee, in accordance with local standards.

Once the survey was completed, participants received material on smoking risks, contact data to receive smoking cessation counseling, and a guideline on how healthcare professionals should act regarding their patients' smoking. All data were collected in an anonymous and confidential manner. 


\section{RESULTS}

The survey was administered in May 2011, with $480(69.7 \%)$ of 689 staff residents present at their hospitals; the rest of the physicians were absent due to turnover, leaves or service reasons. All accepted to complete the survey. Out of 480 surveys collected, 32 were excluded due to completion mistakes, so the analysis included data from 448 surveys (Table 1).

Smoking prevalence among pediatric residents was $20.1 \%$ (95\% CI: 16.5-24.2) (90/448) (Table 2).

Age at the onset of smoking habit was $17.2 \pm 2.9$ years old. Open spaces were identified as the most common place to smoke inside the hospital by $45.1 \%$ of the surveyed residents. In relation to how entering the residency program affected their habit, $29.8 \%$ referred that they started smoking more after beginning the residency, while $27.4 \%$ quitted smoking, and $15.3 \%$ reduced tobacco use.

No significant differences were found between smokers and non-smokers in terms of gender, having children, number of weekly on-call shifts, or having a direct supervisor who smoked (Table 3).

The history of having a smoking parent was a risk factor for tobacco use only among women (OR: 1.98 ; 95\% CI: 1.09-3.61; $\mathrm{p}=0.01$ ).

Those living with a couple smoked less than those who lived on their own, with their parents, relatives or friends $(15.4 \%$ versus $23.4 \%$; $p=0.05$; OR: 0.6; 95\% CI: 0.25-1).

Regarding their behavior towards smoking patients, $46.7 \%$ indicated that they always asked their patients and their parents if they smoked; $37.7 \%$ always warned them about smoking risks, and $32.4 \%$ always advised them on how to quit smoking or prevent them from starting, with
$18.1 \%$ having an active behavior (always ask, warn and advise) (see Table 2). Those who had received information on this issue during their training referred that they asked and advised their patients more frequently than those who had not (OR: 1.58; 95\% CI: 1.05-2.38; $\mathrm{p}=0.02$ and OR: $1.63 ; 95 \%$ CI: 1.04-2.55; $\mathrm{p}=0.02$, respectively), with no significant differences in terms of warning (OR: 1.49; 95\% CI: 0.97-2.28; $\mathrm{p}=0.05$ ). No behavioral differences were found between smokers and non-smokers, but those who had received information during their training most usually had an active behavior (OR: 2.09; 95\% CI: 1.20-3.65; $p=0.005$ ).

Multivariate analysis: when age, gender, number of on-call shifts, living with a couple, smoking father, smoking mother, and smoking supervisor are included in a multivariate model, only the fact of living with a couple appeared to be a protective factor against smoking (OR: 0.57; 95\% CI: 0.34-0.96; $p=0.03$ ).

A second multivariate model was developed to evaluate active behavior with the inclusion of age, gender, smoking father, smoking mother, smoking resident, and having received information. Only receiving information during training was an independent predictor of having an active behavior towards their patients' or parents' smoking (OR: 1.98; 95\% CI: 1.16-3.36; $\mathrm{p}=0.012$ ).

Comparison with the previous study: no significant decrease in smoking prevalence was observed (20.1\% versus $22.1 \%$; OR: $0.89 ; 95 \% \mathrm{CI}$ : $0.62-1.27 ; p=0.5)$, but there was a higher rate of resident pediatricians who advised $(32.4 \%$ versus 26.1\%; OR: 2.09 ; 95\% CI: 1.48-2.96; $\mathrm{p}=0.00001)$ and warned their patients ( $37.7 \%$ versus $18.6 \%$; OR:

TABLE 1. Distribution of participating resident pediatricians by hospital

\begin{tabular}{|c|c|c|c|c|c|c|}
\hline \multirow[t]{2}{*}{ Hospital } & \multirow[t]{2}{*}{ City } & \multirow[t]{2}{*}{$\begin{array}{c}\text { Total } \\
\text { residents }\end{array}$} & \multicolumn{2}{|c|}{ participants } & \multicolumn{2}{|c|}{$\begin{array}{l}\text { Percentage out } \\
\text { of the total }\end{array}$} \\
\hline & & & $\mathbf{n}$ & $\%$ & 2011 & 2002 \\
\hline Elizalde & Buenos Aires & 116 & 99 & 85.3 & 22.1 & 27.5 \\
\hline Garrahan & Buenos Aires & 145 & 54 & 37.2 & 12.1 & 9.5 \\
\hline Gutiérrez & Buenos Aires & 154 & 90 & 58.4 & 20.1 & 18.9 \\
\hline Santísima Trinidad & Córdoba & 85 & 49 & 57.6 & 10.9 & 12.6 \\
\hline lnfantil & Córdoba & 53 & 51 & 96.2 & 11.4 & 10.0 \\
\hline Sor María Ludovica & La Plata & 78 & 53 & 67.9 & 11.8 & 10.9 \\
\hline Notti & Mendoza & 44 & 39 & 88.6 & 8.7 & 7.4 \\
\hline Castro Rendón & Neuquén & 14 & 13 & 92.9 & 2.9 & 3.2 \\
\hline Total & & 689 & 448 & 65.0 & 100.0 & 100.0 \\
\hline
\end{tabular}


1.76; $95 \%$ CI: 1.25-2.36; $\mathrm{p}=0.0005)$. In addition, there was a higher percentage of women in the residency $(83.3 \%$ versus $76.2 \%$; OR: $1.55 ; 95 \% \mathrm{CI}$ : $1.08-2.23 ; p=0.013$ ) and a higher percentage of residents who had received information during

TABLE 2. Distribution of outcome measures assessed in the studied population $(n=448)$

\begin{tabular}{lc}
\hline Characteristics & Percentage \\
\hline Year of Pediatric Residency & \\
$\quad$ ler year & 25.7 \\
2nd year & 25.7 \\
$\quad$ 3rd year & 28.6 \\
Female & 83.3 \\
Smokers & 20.1 \\
Living alone & 25.5 \\
Living with a couple & 40.7 \\
With children & 8.5 \\
Smoking mother & 45.5 \\
Smoking father & 60 \\
Smoking father and mother & 33.9 \\
Either smoking father or mother & 71.7 \\
Smoking direct supervisor & 47.3 \\
Received information & 63.6 \\
Always asks & 46.7 \\
Always warns & 37.7 \\
Always advises & 32.4 \\
Active behavior & 18.1 \\
\hline
\end{tabular}

their training $(63.6 \%$ versus $39.8 \%$; OR $2.67 ; 95 \%$ CI: 1.98-3.60; $\mathrm{p}<0.001)$ (Table 4).

\section{DISCUSSION}

Results showed that $20.1 \%$ of pediatric residents were smokers. In spite of the measures implemented to reduce tobacco exposure and use over the past years, smoking prevalence in the studied population did not change when compared to $2002(22.1 \%){ }^{7}$ This trend is similar to that observed at a national level in the same age group (25-34 years old) between $2005(34.6 \%)^{11}$ and $2009(33.3 \%) .^{10}$

If compared to what Haddock describes ${ }^{12}$ in pediatric residents from New Jersey $(7 \%)$, the prevalence of smoking among Argentine pediatric residents is high. However, such prevalence is lower than that reported for Argentine medicine students and medical practitioners. The F.U.M.Ar study, ${ }^{13}$ conducted in 2004 in 12 schools of medicine in Argentina, estimated a smoking prevalence of $35.2 \%$ among students, while the TAMARA study ${ }^{14}$ reported a prevalence of $30.2 \%$ in a sample of almost 6500 Argentine physicians.

Although physicians are aware of the consequences and resulting morbidity and mortality of tobacco use, the difference in smoking rates between physicians and the general population is still low in Argentina. In developed countries, this difference is much

TABLE 3. Comparison of the distribution of potential predictors among current smoking resident pediatricians and non-smokers

\begin{tabular}{|c|c|c|c|c|c|}
\hline Characteristics & Smokers & Non-smokers & OR & $95 \% \mathrm{CI}$ & $p$ \\
\hline Age (years) & $28.76 \pm 2.05$ & $28.37 \pm 2.08$ & & & 0.11 \\
\hline Male & $15.6 \%$ & $17 \%$ & 0.90 & $0.45-1.75$ & 0.74 \\
\hline Female & $84.4 \%$ & $83 \%$ & 1.11 & $0.57-2.21$ & 0.74 \\
\hline On-call shifts ( 2 or more) & $81.1 \%$ & $72 \%$ & 1.66 & $0.91-3.09$ & 0.08 \\
\hline Living on your own & $32.2 \%$ & $23.8 \%$ & 1.52 & $0.89-2.59$ & 0.1 \\
\hline Living with a couple & $31.1 \%$ & $43.1 \%$ & 0.60 & $0.35-1.00$ & 0.03 \\
\hline With children & $7.8 \%$ & $8.7 \%$ & 0.89 & $0.34-2.21$ & 0.79 \\
\hline Smoking mother & $50 \%$ & $44.4 \%$ & 1.25 & $0.77-2.04$ & 0.34 \\
\hline Smoking father & $68.9 \%$ & $57.8 \%$ & 1.62 & $0.96-2.73$ & 0.05 \\
\hline Both smoking parents & $38.9 \%$ & $32.7 \%$ & 1.31 & $0.79-2.17$ & 0.27 \\
\hline Smoking mother or father & $80 \%$ & $69.5 \%$ & 1.75 & $0.97-3.20$ & 0.04 \\
\hline Female - smoking father & $73.7 \%$ & $58.6 \%$ & 1.98 & $1.09-3.61$ & 0.01 \\
\hline Female - smoking mother & $52.6 \%$ & $44.8 \%$ & 1.37 & $0.80-2.34$ & 0.22 \\
\hline Male - smoking father & $42.8 \%$ & $54.1 \%$ & 0.64 & $0.17-2.35$ & 0.45 \\
\hline Male - smoking mother & $35.7 \%$ & $42.6 \%$ & 0.75 & $0.19-2.85$ & 0.64 \\
\hline Smoking direct supervisor & $48.9 \%$ & $46.9 \%$ & 1.08 & $0.66-1.76$ & 0.74 \\
\hline Received information & $61.1 \%$ & $64.2 \%$ & 0.87 & $0.53-1.45$ & 0.58 \\
\hline Active behavior & $21.1 \%$ & $20.4 \%$ & 1.04 & $0.57-1.91$ & 0.88 \\
\hline
\end{tabular}


higher, with smoking prevalences between physicians and the general population of $6 \%$ and $40 \%$, respectively, in The Netherlands, ${ }^{15,16}$ of $5.5 \%$ and $23 \%$, respectively, in Finland, ${ }^{17,18}$ of $17 \%$ and $35 \%$, respectively, in Japan, ${ }^{18,19}$ and of $4 \%$ and $23 \%$, respectively, in the USA. ${ }^{18,20}$

Unlike the study conducted in 2002, which showed an increase in tobacco use after entering the residency (38.9\% smoked more after starting), this study indicated that such percentage decreased to $29.8 \%$. This can be explained, in part, by the implementation of certain measures over the past years aiming at improving residents' quality of life, such as a reduction in the number of on-call shifts or the implementation of a break after a 24 hour shift at several hospitals. ${ }^{21}$

Although the studies done in Argentina focus on analyzing tobacco use among different specialty physicians, ${ }^{14}$ there are no data in our field regarding smoking among residents of other specialties that would allow to make a comparative analysis with the studied population.

Almost half of the smokers (45.1\%) indicated that they most commonly smoked in the hospital's open spaces. Although some of the districts included do not prohibit smoking in open spaces, in others, such as the Autonomous City of Buenos Aires (where more than $50 \%$ of the studied population work), smoking in health facilities is absolutely banned. ${ }^{22}$

Genetic, environmental, and cultural factors have been associated to tobacco use. This study found that having a smoking parent was a risk factor, consistent with the evidence that indicates that parental smoking is a risk factor for smoking initiation among adolescents..$^{23-26}$

It is difficult to compare the residents' preventive attitude (ask, warn, advise) with other experiences because this information was collected differently in each study. However, as observed by other authors, ${ }^{12,27}$ in this study results show that residents advised and warned their patients less than asked about smoking, because advising and warning require more knowledge on smoking cessation and capacity. Consistent with this, those who had received information during their training or residency tended to have a more active behavior towards smoking cessation (ask, warn and advise) than those who had not. Barnes Dodge ${ }^{27}$ found that $83 \%$ of participants indicated that they asked about smoking, but only $36 \%$ advised their patients or caregivers to quit smoking, and that knowledge on smoking cessation resources was the factor most associated with such behavior. Evidence shows that specific training on this topic increases active behavior among healthcare professionals towards their patients' smoking. ${ }^{28-30}$ However, since this is a survey administered to physicians, it should be noted that their active behavior could be overestimated. Few studies have collected data from patients: two studies conducted by Hymowitz, ${ }^{28,31}$ indicate that only $10 \%$ and $21 \%$ of smokers, respectively, reported that their physician had offered them help to quit. The improvement observed in studied behaviors (ask, warn, and advise) can be related to a higher rate of healthcare professionals who received information on smoking cessation.

The high rate of participants that indicated having received information on smoking habit $(63 \%)$ contrasts the $5.2 \%$ of medicine students who admitted having received formal training on smoking cessation in the Global Health Professions Student Survey (GHPSS). This demonstrates a deficiency in under-graduate training. Such difference can be explained because in our study we asked about having received information instead of asking about formal training, which underscores the difference between acquiring knowledge and the capacity to put it in practice. In addition, and although it was not part of the data collected in this survey, most participating facilities lack specific tools for an

TABLE 4. Comparison with the results of the 2002 survey $^{7}$

\begin{tabular}{lccccc}
\hline & $\mathbf{2 0 0 2}$ & $\mathbf{2 0 1 1}$ & OR & IC 95\% & $p$ \\
\hline Smoking & $22.1 \%$ & $20.1 \%$ & 0.89 & $0.62-1.27$ & 0.5 \\
Female & $76.2 \%$ & $83.3 \%$ & 1.55 & $1.08-2.23$ & 0.013 \\
Received information & $39.8 \%$ & $63.6 \%$ & 2.67 & $1.98-3.60$ & $<0.001$ \\
Always asks & $39.5 \%$ & $46.4 \%$ & 1.33 & $0.99-1.78$ & 0.05 \\
Always warns & $18.6 \%$ & $37.7 \%$ & 1.72 & $1.25-2.36$ & $<0.001$ \\
Always advises & $26.1 \%$ & $32.4 \%$ & 2.09 & $1.48-2.96$ & $<0.001$ \\
\hline
\end{tabular}


effective smoking cessation intervention, which limits the possibility of an actual intervention on reducing tobacco exposure.

The minimum number of changes in tobacco use among pediatric residents in Argentina is possibly related to the fact that, although Argentina became a part of the World Health Organization Framework Convention on Tobacco Control in 2003, it has not yet ratified its adherence to the convention nor complied with its provisions.

\section{CONCLUSIONS}

Among resident pediatricians, 20.1\% were smokers, with a higher prevalence among women with a smoking parent. The rate of active behavior regarding patients or parents who smoke was very low. In spite of official policies, tobacco use in this group has not changed over the past decade, but there was an increase in the rate of those who received information during their training and of those who advised their patients of smoking risks.

\section{REFERENCES}

1. World Health Organization. WHO global report mortality attributable to tobacco. Geneva:World Health Organization; 2012. [Accessed on: June 1, 2012]. Available at: http:// whqlibdoc.who.int/ publications/2012/9789241564434_ eng.pdf.

2. Argentina. Ministerio de Salud y Ambiente de la Nación. Costos Directos dela Atención médica de las enfermedades atribuibles al consumo de tabaco en Argentina. Proyecto VIGIA. Buenos Aires: Ministerio de Salud y Ambiente de la Nación; 2005. [Accessed on: June 1, 2012]. Available at: http://msal.gov.ar/htm/site_tabaco11/pdf/costos_ directos_at_medica.pdf.

3. Patiño C. El rol del médico en la lucha antitabáquica. Alerg Inmunol Clin 2000;17(Suppl 1):s26.

4. Stein RJ, Haddock CK, O'Byrne KK, Hymowitz N, Schwab $\mathrm{J}$. The pediatrician's role in reducing tobacco exposure in children. Pediatrics 2000;106(5):e66.

5. Grupo Tabaquismo. Consenso sobre factores de riesgo de enfermedad cardiovascular en pediatría. Tabaquismo. Arch Argent Pediatr 2005;103(5):464-75.

6. Moreno MA. Resident stress revisited: a senior pediatric resident's point of view. Pediatrics 2003;112(2):411-4.

7. Ferrero F, Castaños C, Durán P, Blengini MT. Prevalencia del consumo de tabaco en médicos residentes de pediatría en Argentina. Rev Panam Salud Pública 2004;15(6):395-9.

8. Organización Mundial de la Salud. Convenio Marco de la OMSparaelControldelTabaco.WHODocumentProduction Services;2003. [Consulta:June 1,2012]. Availableat: http:/ / whqlibdoc.who.int/publications/2003/9243591010.pdf.

9. Secretaría de Programación para la prevención de la Drogadicción y la Lucha contra el Narcotráfico (SEDRONAR). Estudio Nacional sobre consumo de sustancias adictivas. Buenos Aires, Argentina; 1999.

10. Ferrante D, Linetzky B, Konfino J, King A, et al. Encuesta Nacional de Factores de Riesgo 2009: Evolución de la epidemia de enfermedades crónicas no transmisibles en
Argentina. Estudio de corte transversal. Rev Argent Salud Pública 2011;2(6):34-41.

11. Argentina. Ministerio de Salud de la Nación. Encuesta Nacional de Factores de Riesgo 2005 -Informe de Resultados. Argentina; 2005. [Accessed on: June 1, 2012]. Available at: http://msal.gov.ar/ENT/VIG/Areas Tematicas /Factores_de_Riesgo/PDF/Encuesta $\% 20$ Nacional\%20de\%20Factores\%20de\%20Riesgo\%202005_ informe_final_breve.pdf.

12. Haddock CK, Pyle S, Hymowitz N, Schwab J, et al. Which pediatric residents assist and arrange follow-up for patients and parents who use tobacco? J Adolesc Health 2005;36(6):531-3.

13. Zabert G, Verra F, Kevorkof G, Lungo B, et al. Estudio F.U.M.Ar (Fumar en Universitarios de Medicina en Argentina). Informe final. 2004. [Accessed on: June 1, 2012]. Available at: http://www.msal.gov.ar/tabaco/images/ stories/info-equipos-de-salud/pdf/paper-fumar-2004v4CAEM-2005.pdf.

14. Zylbersztejn HM, Cardone A, Vainstein N, Mulassi A, ET al. Tabaquismo en médicos de la República Argentina: Estudio TAMARA. Rev Argent Cardiol 2007;75(2):109-16.

15. Kotz D, Wagena EJ, Wesseling G. Smoking cessation practices of Dutch general practitioners, cardiologists, and lung physicians. Respir Med 2007;101(3):568-73.

16. World Health Organization. Highlights on Health in the Netherlands. World Health Organization; 1997. [Accessed on: June 1, 2012]. Available at: http://www.euro.who. int/_data/assets/pdf_file/0018/130536/E62040.pdf.

17. Barengo NC, Sandstr6m PH, Jormanainen VJ, Myllykangas MT. Changes in smoking prevalence among Finnish physicians 1990-2001. Eur J Public Health 2004;14(2):201-3.

18. Shafey O, DolwickS, Guindon E. Tobacco Control Country Profiles 2003. Atlanta, GA: American Cancer Society; 2003.

19. Ohida T,Sakurai H, Mochizuki Y,KamalAM, etal.Smoking prevalence and attitudes toward smoking among Japanese physicians. JAMA 2001;285(20):2643-8.

20. Lee DJ, LeBlanc W, Fleming LE, Gómez-Marín O, et al. Trends in US smoking rates in occupational groups: the National Health Interview Survey 1987-1994. J Occup Environ Med 2004;46(6):538-48.

21. Ley $N^{\circ}$ 601. Modificación del Régimen de Residencias. Boletín Oficial de la Ciudad de Buenos Aires N 1232. Buenos Aires, Argentina, 13 de julio de 2001.

22. Ley $\mathrm{N}^{\circ} 1799$. Ley de Control del Tabaco. Boletín Oficial de la Ciudad de Buenos Aires $N^{\circ} 2313$. Buenos Aires, Argentina, 8 de noviembre de 2005.

23. Cogollo-Milanés Z, La Hoz-Restrepo F de. Consumo de cigarrillo y riesgo de dependencia de la nicotina de estudiantes de secundaria. Rev Salud Publica (Bogotá) 2010;12(3):434-45.

24. Giannakopoulos G, Tzavara C, Dimitrakaki C, Kolaitis $\mathrm{G}$, et al. Emotional, behavioural problems and cigarette smoking in adolescence: findings of a Greek cross-sectional study. BMC Public Health 2010;10:57.

25. Bricker JB, Peterson AV, Robyn Andersen M, Leroux BG, et al. Close friends', parents', and older siblings' smoking: reevaluating their influence on children's smoking. Nicotine Tob Res 2006;8(2):217-26.

26. FergussonDM,Horwood LJ, BodenJM,JenkinG.Childhood social disadvantage and smoking in adulthood: results of a 25-year longitudinal study. Addiction 2007;102(3):475-82.

27. Barnes Dodge RA, Cabana MD, O'Riordan MA, Heneghan A. What factors are important for pediatric residents' smoking cessation counseling of parents? Clin Pediatr (Phila) 2008;47(3):237-43. 
28 Hymowitz N, Schwab JV, Haddock CK, Pyle SA, et al. The pediatric residency training on tobacco project: four-year resident outcome findings. Prev Med 2007;45(6):481-90.

29 Collins RL, D'AngeloS, Stearns SD, Campbell LR. Training pediatric residents to provide smoking cessation counseling to parents. Scientific World Journal 2005;5:410-9.

30. Lee MT, Hishinuma ES, Derauf C, Guerrero APS, et al. Smoking cessation counseling training for pediatric residents in the continuity clinic setting. Ambul Pediatr 2004;4(4):289-94.
31. Hymowitz N, Schwab J, Haddock CK, Pyle S, et al. The pediatric resident training on tobacco project: baseline findings from the Parent/Guardian Tobacco Survey. Prev Med 2005;41(1):334-41.

32. Global Health Professions Student Survey (GHPSS). FACT SHEET Argentina - Medical Students (3rd Year Students Only). [Consultado: June 1, 2012]. Available at: http://new.paho.org/hq/dmdocuments/2010/2005\%20 Argentina $\% 20$ GHPSS $\% 20 \% 28$ Medical $\% 29$ 